\title{
Inclusion of children with cerebral palsy in basic education
}

\author{
Inclusão de crianças com paralisa cerebral em escola de ensino fundamental \\ La inclusión de niños con parálisis cerebral en escuela primaria \\ Geovana Sôffa Rézio', Cibelle Kayenne Martins Roberto Formiga²
}

\begin{abstract}
I The aim of the study was to analyze the inclusion of children with cerebral palsy in elementary schools. The sample consisted of 31 children between 1 and 11 years old, with a mean of 5 years and 2 months, coming from 2 rehabilitation centers and their leaders and teachers. As for functionality, $71 \%$ are Gross Motor Function Classification System (GMFCS) level I, 51.6\% are diplegic and $58.1 \%$ had cerebral palsy during the prenatal stage. Regarding economic classification, 54.8\% of the families were in class $C$. A neurological evaluation form was applied. A gross motor evaluation using the GMFCS; a socioeconomic assessment using the Brazilian Criteria for Economic Classification and the School Function Assessment were done. The results revealed that these children perform their activities in all aspects of the school participation, although they require constant supervision, moderate assistance and minimal adaptation. These results may be useful to better adapt the school environment, for a better targeting of assistance provided and to plan clinical interventions with these children.
\end{abstract}

Keywords I Cerebral Palsy; Child; Child, Preschool;

Education, Primary and Secondary.

RESUMO I O objetivo do estudo foi analisar a inclusão de crianças com paralisia cerebral em escolas de ensino fundamental. A amostra foi composta por 31 crianças, entre 1 e 11 anos, com média de 5 anos e 2 meses, oriundas de 2 centros de reabilitação e seus respectivos responsáveis e professores. Quanto à funcionalidade, $71 \%$ são nível
I do Sistema de Classificação da Função Motora Grossa (GMFCS), 51,6\% são diplégicas e 58,1\% tiveram paralisia cerebral durante a fase pré-natal. Quanto à classificação econômica, 54,8\% das famílias das crianças pertenciam à classe C. Foram aplicadas: ficha de avaliação neurológica, avaliação motora grossa utilizando o GMFCS, avaliação socioeconômica com o Critério de Classificação Econômica Brasil. A função escolar foi avaliada utilizando o School Function Assessement. Os resultados revelaram que essas crianças realizam suas atividades em todos os aspectos da participação escolar, porém necessitam de uma supervisão constante, uma assistência moderada e uma adaptação mínima. Esses resultados podem ser úteis para uma melhor adaptação do meio escolar, melhor direcionamento das assistências fornecidas e planejamento das intervenções clínicas com essas crianças.

Descritores I Paralisia Cerebral; Criança; Pré-Escolar; Ensino Fundamental e Médio.

RESUMEN I El objetivo del estudio fue analizar la inclusión de niños con parálisis cerebral en escuelas de enseñanza básica. La muestra fue compuesta de 31 niños entre 1 y 11 años, con un promedio de 5 años y 2 meses, las cuales venían de 2 centros de rehabilitación, y sus respectivos responsables y maestros. En cuanto a la funcionalidad, 71\% son nivel I del Sistema de Clasificación de la Función Motora Gruesa (GMFCS), 51,6\% son dipléjicos y el $58,1 \%$ tienen parálisis cerebral durante la etapa prenatal. En cuanto a la clasificación económica, el 54,8\% de las

Study conducted at the Centro de Orientação e Assistência ao Encafalopata (CORAE) and at the Pestalozzi, Renascer branch - Goiânia (GO), Brazil.

'Graduate Program in Environmental and Health Sciences by the Pontifícia Universidade Católica de Goiás (PUC-GO) - Goiânia (GO), Brazil. ¿Universidade Estadual de Goiás (UEG) - Goiânia (GO), Brazil. 
familias de los niños pertenecía a la Clase C. Fueron aplicados: formulario de evaluación neurológica, evaluación motora gruesa utilizando el GMFCS, evaluación socioeconómica con el Criterio de Clasificación Económica Brasil. La función escolar fue evaluada utilizando el School Function Assessement. Los resultados revelaron que estos niños llevan a cabo sus actividades en todos los aspectos de la participación escolar, pero necesitan una supervisión constante, una asistencia moderada y adaptación mínima. Estos resultados pueden ser útiles para mejor adaptación del ambiente escolar, mejor orientación de la asistencia prestada y planificación de las intervenciones clínicas con estos niños. Palabras clave I Parálisis Cerebral; Niño; Preescolar; Educación Primaria y Secundaria.

\section{INTRODUCTION}

The term cerebral palsy $(\mathrm{CP})$ or chronic non-progressive encephalopathy appeared in 1964, when Bax first conceptualized it as a disorder of movement and posture, due to a defect or lesion in the immature brain ${ }^{1}$.

The CP describes a group of permanent disorders in development, movement and posture, causing limitations in activities, which are attributed to non-progressive disturbances that occurred during fetal development or in the infant brain. The motor alterations of $\mathrm{CP}$ are often accompanied by disturbances of sensation, perception, cognition, communication, behavior, epilepsy and secondary musculoskeletal issues ${ }^{2}$.

Children with $\mathrm{CP}$ do not go through health professionals alone, but also through education professionals, such as educators and educational psychologists. However, the inclusion of these children in basic educations classrooms has been a challenge for the school community, the family and health services. In early childhood education, several factors influence children in the school environment. To be more specific, one may cite organizational and administrative aspects, the physical space, the routines, the institution's practices and the processes for educators' training ${ }^{3}$.

In the early 1990s, with the Salamanca Statement on Principles, Policy and Practice in Special Needs Education $^{4}$, the right of every child to receive education was assured to special needs students (PNEE). In Brazil, the enactment of the Law No. 9.394/96 - Nova Lei de Diretrizes e Bases Nacional (LDB) - was of fundamental importance in order to justify the right to education wihtou exclusion for $\mathrm{PNEE}^{5}$.

It is known that the admission of children in school environment is each year more precocious, due to the inclusion of mothers in the job market. Also, the participation of children in school life may provide them with stimulation in various neurodevelopment areas, having an important role in helping children with special needs who require medical treatments.
In this sense, the present study is justified by the contribution to researchers and professionals who work with these children whether in clinical or educational context, aiming at the improvement of these children's school functions, both on preschool and school levels.

The study aimed at analysing the inclusion of children with $\mathrm{CP}$ in elementary schools by the School Function Assessement (SFA), which assesses school functions of children in their educational environment.

\section{METHODOLOGY}

31 children diagnosed with $\mathrm{CP}$, from both genders, aged between 1 and 11 years of age, who regularly attend to the Clinical Section of the Pestalozzi Association in Goiânia (Renascer branch) and the Center of Guidance, Rehabilitation and Assistance to Encephalopathy (CORAE), in Goiânia, Goiás, took part in this study, along with their respective parents and/or guardians and the teachers.

This study was conducted according to the Regulatory Guidelines and Standard for Research Involving Humans (Resolution 196/1996 of the National Health Council) and approved by the Ethics in Research Committee of the Universidade Federal de Goiás (UFG) (approval No. 0205/10).

\section{Functional Classification}

The Gross Motor Function Classification System (GMFCS) was used to classify the level of motor function of the children. It is an instrument designed on an ordinal scale of five levels, in decreasing order. The higher the level, the worse the performance of the child, i.e., a greater number of functional limitations. Thus, the children in the research were only classified at levels I to III, for presenting a higher level of motor functions. 


\section{Neurological assessment sheet}

The neurological assessment sheet consists of anamnesis information from the parents and/or guardians and data from neurological assessment performed with the child.

\section{Socioeconomic assessment}

The Brazilian Economic Classification Criterion (CCEB) uses a survey of household characteristics (presence and amount of certain household comfort items and level of education of the head of the household) to differentiate the population. It is then made a comparison between the criteria score range and the levels of economic classification, defined by A1, A2, B1, $\mathrm{B} 2, \mathrm{C} 1, \mathrm{C} 2, \mathrm{D}$ and $\mathrm{E}$.

\section{School participation}

The school function refers to the ability of the student to play important functional activities, which support or enable participation in educational and social aspects related to an educational program.

The SFA consists of questions on social participation, achievement of tasks and activities. The score was given comparing children of the same series, despite their chronological age. The SFA is divided into three parts: I - Social participation; II - Assistance in performing tasks; III - Performance in activities. This research used the parts I and II of the instrument, because the aim was to assess how much assistance from others and adaptations are necessary for the student to perform the task without delving into the performance of the student's activities (part III). The SFA has been used both for children in pre-school and older school, as all of them would attend the same educational environment, according to their methods of teaching, special or regular students.

\section{Social participation}

Assesses the level of student participation in the main school settings: classroom, playground/break, transportation from/to school, toilet/hygiene, transition (shifting through different environments within the school), snack/meal. The scores for each item of school environments follow the following classification: $1-\mathrm{ex}-$ tremely limited participation; 2 - participation in some activities; 3 - participation in all aspects with constant supervision; 4 - participation in all aspects with occasional assistance; 5 - full modified participation; and 6 - full participation. Higher scores equal better performance of the child, i.e., greater independence in social participation.

\section{The assistance in task performance}

Evaluates the necessary support, other than the one provided to the other students, so that the student performs the task. Two aspects are evaluated: the assistance of others (students, staff and teachers) and the adaption to the environments, equipment and/or programs, both in physical and cognitive-behavioral tasks. Physical tasks include: physical relocation movements, maintenance and change of position; recreational activities; manipulating objects with movement, use of materials in the classroom; organization and cleanliness; eating and drinking, hygiene; handling clothes; going up and down stairs; written jobs; use of computers and equipments. The cognitive-behavioral tasks include tasks of functional communication, memory and understanding; respecting social conventions; obeying school rules and orders from adults; behavior in tasks and the completion of them; positive interaction with peers; regulation of behavior; awareness of personal care and safety.

The score varies for both aspects respectively at: 1 - extensive assistance/extensive adaptation; 2 - moderate assistance/moderate adaptation; 3 - minimum assistance/minimum adaptation; 4 - no assistance/no adaptation. Higher values equal better performance of the child, i.e., greater independence in performing tasks.

After the authorization by the parents/guardians of the child, an assessment was performed with the GMFCS, in order to classify them in relation to gross motor function. As to characterize the sample, parents/ guardians have answered, through an interview, a neurological assessment and a socioeconomic evaluation form. The SFA questionnaire was completed by teachers with the help of a researcher.

\section{Data analysis}

The descriptive analysis (average, standard deviation, minimum and maximum values, frequencies and percentages) of the data was performed using the Statistical Package for Social Science (SPSS) software, version 15.0. 


\section{RESULTS}

The sample consisted of 31 children with CP, 16 of them being female children. The ages ranged from 1 year and 6 months to 11 years of age (average age: 5 years and 2 months). As for functionality, 71\% were level I in the GMFCS, 51.6\% were diplegic and $58.1 \%$ had $\mathrm{CP}$ during the prenatal stage. As to the economic classification, $54.8 \%$ of the children's families were in class $\mathrm{C}$.

Of the total of 31 children, 24 attend special education at the institution where they receive clinical care, of those, only 6 also attend regular school. The remaining seven children only attend regular school. Age did not affect the level of school function of these children.

When it comes to school participation, children with $\mathrm{CP}$ perform the activities in all aspects, but they require, however, constant supervision. The student who had maximum score presents full participation and the one who had a minimum score has an extremely limited participation. During the tasks and the activities associated with eating at school (mealtime/ snack), the child participates in all aspects, although they need occasional assistance, different from their school participation in transportation (go and come back from school and the transferences in the vehicle), which is more limited (Table 1).

Regarding the assistance to physical tasks in school participation, children need a moderate to minimal assistance in activities. The child with the highest score does not need assistance, and the one with the lowest score requires an extensive assistance in order to have a stake in relation to physical tasks. Hygiene (to perform tasks in the bathroom) and the handling of clothes (dressing and undressing clothes) were the tasks which required more assistance (moderate assistance), whereas the maintenance and change of positions (changing position and maintain posture) was the task which required minimal assistance (Table 2).

Regarding adaptations in physical tasks, children need a minimum adaptation in order to participate in school activities. The student with the highest score does not have the need for adjustment and the one who had the lowest score requires extensive adaptation. During manipulation tasks and activities with movement, that involved carrying and manipulating objects during transferences, children do not require adjustments. In the handling of clothes (dressing and undressing clothes), they required minimal adaptation (Table 3).
As it comes to cognitive/behavioral tasks, children require moderate assistance to participate in school activities, especially in self-care and safety. The student who had maximum score does not need assistance and the one who got the minimal score needs extensive assistance (Table 4).

In the adaptation of cognitive/behavioral tasks, children need a minimum adaptation in order to participate in school activities, especially in following the rules/social expectations (to respect privacies, to have boundaries, to use appropriate language) and behavior/completion of the task (to keep focused and paying attention to tasks). The child who had top scores here requires no adjustment and the one who had minimum score requires extensive adaptation (Table 5).

Table 1. Description of the school participation of children with cerebral palsy - participation

$\begin{array}{lccc}\text { Participation } & \text { Mean } \pm \text { SD } & \text { Minimum } & \text { Maximum } \\ \text { Regular or special classroom } & 3.3 \pm 1.2 & 1 & 5 \\ \text { Recreation patio/break } & 3.6 \pm 1.3 & 1 & 6 \\ \text { Transportation } & 2.6 \pm 1.5 & 1 & 6 \\ \text { Restroom/personal hygiene } & 3.4 \pm 1.9 & 1 & 6 \\ \text { Transitions } & 2.8 \pm 1.2 & 1 & 6 \\ \text { Mealtime/snack } & 4 \pm 1.4 & 2 & 6 \\ \text { Total average } & 3.2 \pm 1.4 & - & -\end{array}$

Table 2. Description of the school participation of children with cerebral palsy - Physical tasks / assistance

$\begin{array}{lccc}\text { Physical tasks/assistance } & \text { Mean } \pm \text { SD } & \text { Minimum } & \text { Maximum } \\ \text { Relocation movement } & 2.8 \pm 1 & 1 & 4 \\ \text { Maintenance and change of } & & & \\ \text { positions } & 3.0 \pm 1 & 2 & 4 \\ \text { Recreational activities } & 2.5 \pm 1 & 1 & 4 \\ \text { Manipulation with movement } & 2.7 \pm 1.1 & 1 & 4 \\ \text { Usage of materials } & 2.3 \pm 1.3 & 1 & 4 \\ \text { Organization and cleanliness } & 2.4 \pm 1.1 & 1 & 4 \\ \text { Eating and drinking } & 2.8 \pm 1 & 1 & 4 \\ \text { Hygiene } & 2.0 \pm 1.1 & 1 & 4 \\ \text { Clothes handling } & 2.0 \pm 1.3 & 1 & 4 \\ \text { Total average } & 2.5 \pm 1.1 & - & -\end{array}$

Table 3. Description of the school participation of children with cerebral palsy - Physical tasks / adaptations

$\begin{array}{lccc}\text { Physical tasks/adaptations } & \text { Mean } \pm \text { SD } & \text { Minimum } & \text { Maximum } \\ \text { Relocation movement } & 3 \pm 1 & 2 & 4 \\ \text { Maintenance and change of } & & & \\ \text { positions } & 2.9 \pm 1 & 1 & 4 \\ \text { Recreational activities } & 3 \pm 1 & 1 & 4 \\ \text { Manipulation with movement } & 3.6 \pm 1 & 2 & 4 \\ \text { Usage of materials } & 3 \pm 1 & 2 & 4 \\ \text { Organization and cleanliness } & 3 \pm 1 & 1 & 4 \\ \text { Eating and drinking } & 3 \pm 1 & 2 & 4 \\ \text { Hygiene } & 2.8 \pm 1 & 1 & 4 \\ \text { Clothes handling } & 2.7 \pm 1 & 1 & 4 \\ \text { Total average } & 3 \pm 1 & - & -\end{array}$


Table 4. Description of the school participation of children with cerebral palsy - Cognitive-behavioural/assistance

$\begin{array}{lccc}\begin{array}{l}\text { Cognitive-behavioural tasks/ } \\ \text { assistance }\end{array} & \text { Mean } \pm \text { SD } & \text { Minimum } & \text { Maximum } \\ \text { Functional communication } & 2.3 \pm 1.1 & 1 & 4 \\ \begin{array}{l}\text { Memory and understanding } \\ \text { Following the rules/social }\end{array} & 2.4 \pm 1.1 & 1 & 4 \\ \begin{array}{l}\text { expectations } \\ \text { Obedience to the commands of }\end{array} & 2.3 \pm 1.2 & 1 & 4 \\ \text { adults and school rules } & 2.4 \pm 1.1 & 1 & 4 \\ \text { Behavior/completion of the task } & 2.5 \pm 1.1 & 1 & 4 \\ \text { Positive interaction } & 2.5 \pm 1 & 1 & 4 \\ \text { Behavior control } & 2.3 \pm 1.1 & 1 & 4 \\ \text { Selfcare } & 2 \pm 1.1 & 1 & 4 \\ \text { Safety } & 1.9 \pm 1 & 1 & 3 \\ \text { Total average } & 2.3 \pm 1.1 & - & -\end{array}$

Table 5. Description of the school participation of children with cerebral palsy - Cognitive-behavioural/adaptations

\begin{tabular}{lccc}
$\begin{array}{l}\text { Cognitive-behavioural tasks/ } \\
\text { adaptations }\end{array}$ & Mean \pm SD & Minimum & Maximum \\
\hline $\begin{array}{l}\text { Functional communication } \\
\text { Memory and understanding }\end{array}$ & $3.1 \pm 1$ & 2 & 4 \\
$\begin{array}{l}\text { Following the rules/social } \\
\text { expectations }\end{array}$ & $2.9 \pm 1$ & 1 & 4 \\
$\begin{array}{l}\text { Obedience to the commands } \\
\text { of adults and school rules }\end{array}$ & $3 \pm 1$ & 1 & 4 \\
$\begin{array}{l}\text { Behavior/completion of the task } \\
\text { Positive interaction }\end{array}$ & $2.9 \pm 1$ & 1 & 4 \\
$\begin{array}{l}\text { Behavior control } \\
\text { Selfcare }\end{array}$ & $3.1 \pm 1$ & 1 & 4 \\
Safety & $3.1 \pm 1$ & 1 & 4 \\
Total average & $3.1 \pm 1$ & 1 & 4 \\
& $3 \pm 1$ & - & 4
\end{tabular}

\section{DISCUSSION}

This study has identified that children with $\mathrm{CP}$ perform their activities in all aspects of school participation, requiring for that, however, constant supervision. Their participation is more limited during transportation. At mealtime/snack, they participate in all aspects, with constant supervision. In physical tasks, the children require moderate to minimal assistance and minimal adaptation. On the matter of cognitive/behavioral tasks, children require moderate assistance, especially in self-care and safety, and minimal adaptation to engage in school activities.

The results of the present study were similar to the study by Silva et al. ${ }^{6}$ in relation to school participation of children with CP. The authors evaluated 29 students with $\mathrm{CP}$ in regular educational systems, considering the type of school and the degree of motor impairment of the child, who related to the 6 environments of participation of the SFA. The results showed no difference between the type of school and the level of the child's participation. However, the degree of motor impairment proved to be an indication for the level of participation, although it is not clear as to the functionality of the child. Children with greater impairments were less participatory in school environments.

About participation, levels of help and performance in activities in the school routine of children with $\mathrm{CP}$, Silva $^{7}$ corroborates this research, when concluding that the environments with greater difficulties to be faced are bathrooms, transition and transportations, but for the accomplishment of tasks in these environments, students have received high levels of support and a few adaptations. The children with $\mathrm{CP}$ have showed few limitations in cognitive-behavioral tasks. As a suggestion, the study indicates two important aspects to be structured: the need for training programs for teachers and the planning of intervention for children with $\mathrm{CP}$ by a multidisciplinary team, aiming at the improvement on school participation of students with significant motor problems.

Abe's ${ }^{8}$ study concludes that students with $\mathrm{CP}$ required help with physical and cognitive-behavioral tasks; and that they had important difficulties in performing physical tasks in relation to cognitive-behavioral tasks. Therefore, there is a tendency for students to receive more assistance from teachers rather than adaptations and changes in objects, in tasks or on the demands of activities.

The results of this study have identified that children with $\mathrm{CP}$ require assistance from their teachers to carry out their activities at school. The study by Gomes e Barbosa ${ }^{9}$ showed that teachers claim they are not qualified for working in an inclusive school, even presenting negative attitudes towards the inclusive education policy promoted in the country. It is important to consider that these teachers do not consider their responsibility the education of PNEE students. This leads to the need for reviewing what are these educators' beliefs, creeds, values and prejudices, i.e., the position of these teachers, so then they can seek professional qualification in order to act as agents of school inclusion.

With a different sample from the current research, however important to be emphasized because it concerns PNEE children, Ferraz et al. ${ }^{10}$ have conducted a study on the inclusion of children with Down syndrome and $\mathrm{CP}$ in elementary school, comparing the report of stories of mothers and teachers. Teachers report that they are not feeling prepared to work with students with disabilities, but even without guidance, resources 
nor adequate physical infrastructure for these children, they work to improve the conditions of these students in the classroom. It was found that schools often do not create opportunities for parents and teachers to share information and strategies to help children through this process. Schools must prepare to mitigate the difficulties found, because the process of inclusion shows that everyone should learn together and schools are subject to receive students with disabilities.

The research by Silva et al. ${ }^{11}$ has identified that few PNEE attend public schools and this is due to the lack of information of parents, to lack of preparation of schools, and because these schools do not provide the same access conditions to these students. This research corroborates to some extent with the current study when it says these schools are in need of: 1 - multidisciplinary work to encourage the development of student with CP; 2 - overcome prejudices, developed about the education of these students; 3 - making improvements in its physical structure to ensure access and autonomy to these students in all school environments.

Melo e Martins ${ }^{12}$ claim that it is necessary to program more effective and focused actions in relation to the physical and pedagogical organization of schools, such as: prioritizing the development of political-pedagogical projects of educational guidance to school staff who work with students with disabilities; establishing partnerships in order to achieve specific resources and equipment which favor the teaching-learning process; investing on teachers and providing them with support in pedagogical practice; properly adjust the physical structure of the school, minimizing architectural barriers, favoring the autonomy and development of these students in school environment.

Saraiva and $\mathrm{Melo}^{13}$ add that state public schools have certain shortage in suitable furniture for children with CP. This fact, combined with others, makes it rather difficult to the student with $\mathrm{CP}$ to remain in regular school. This explains the results of the current study in relation to the needs of adaptations and the assistance at school.

The inclusion of children and teenagers in the community is an important part of the therapy. What determines the effect of a deficiency in people's lives is the experience with their environment. Therefore, public policies regarding rehabilitation alone are not enough, but rather mechanisms that ensure them equality in social participation in general ${ }^{13}$.

Thus, it appears necessary that health professionals, such as physical therapists and occupational therapists, are present in the school environment in order to bind a partnership with teachers, through guidance and contributions in whatever is necessary for school inclusion and for the performing of adaptations in the environment in which these children with disabilities study.

The more favorable and well structured the school environment is, the greater the possibilities for children with $\mathrm{CP}$ to demonstrate their potentials in their school environment. In this sense, the school needs to pay greater attention to the social and physical characteristics of the environments, ensuring students the opportunities to connect with adapted spaces. The student must not be seen only as a subject in school, but rather as an individual in society.

\section{CONCLUSION}

Through the study's results, it was found that children perform their activities in all aspects of their school participation, but they require, however, constant supervision, moderate assistance and some minimal adaptation. Considering the practical implications of the study, these results may be useful to better adapt the school environment; to better target the assistance provided and to plan clinical interventions with children with cerebral palsy.

\section{REFERENCES}

1. Morris C. Definition and classification of cerebral palsy: a historical perspective. Dev Med Child Neurol Suppl. 2007:109:3-7.

2. Rosenbaum P, Paneth N, Leviton A, Goldstein M, Bax M, Damiano D, et al. A report: the definition and classification of cerebral palsy April 2006. Dev Med Child Neurol Suppl. 2007;109:8-14.

3. Amorim KS, Yazlle C, Rossetti-Ferreira, MC. Saúde e doença em ambientes coletivos de educação de criança de 0 a 6 anos [Internet]. Centro de Investigações sobre Desenvolvimento Humano e Educação Infantil (CINDEDI). 1999. [cited 2011 Jul 23]. Available from: http://www.ced.ufsc.br/ neeOa6/ROSSETTI.pdf

4. UNESCO - United Nations Educational, Scientific and Cultural Organization. The Salamanca statement and framework for action on special needs education. Salamanca, Espanha: UNESCO; 1994.

5. Brasil. Lei no 9.394, de 20 de dezembro de 1996. Estabelece as diretrizes e bases da educação nacional. Diário Oficial da União. Brasília, DF, 1996.

6. Silva AIT, Silva DBR, Agnelli LB, Higuchi MA, Oliveira MC, Silva PC, et al. Perfil funcional de crianças com paralisia cerebral na escola regular segundo tipo de escola e comprometimento motor. Temas Desenvolv. 2004;13(74):5-13. 
7. Silva DBR. Avaliação das atividades de crianças com paralisia cerebral na escola regular: participação, níveis de auxílio e desempenho [dissertação de mestrado] São Carlos: Universidade Federal de São Carlos; 2007.

8. Abe PB. Desempenho funcional nas atividades de rotina escolar de alunos com necessidades especiais na perspectiva do professor [dissertação de mestrado]. Marília: Universidade Estadual Paulista, 2009.

9. Gomes C, Barbosa AJG. Inclusão escolar do portador de paralisia cerebral: atitudes de professores do ensino fundamental. Rev Bras Educ Espec. 2006;12(1):85-100.

10. Ferraz CRA, Araujo MV, Carreiro LRR. Inclusão de crianças com Síndrome de Down e Paralisia Cerebral no ensino fundamental I: comparação dos relatos de mães e professores. Rev Bras Educ Espec. 2010;16(3):397-414.

11. Silva SM, Santos RRCN, Ribas, CG. Inclusão de alunos com paralisia cerebral no ensino fundamental: contribuições da fisioterapia. Rev Bras Educ Espec. 2011:17(2):263-86.

12. Melo FRLV, Martins LAR. Acolhendo e atuando com alunos que apresentam paralisia cerebral na classe regular: a organização da escolar. Rev Bras Educ Espec. 2007;13(1):111-30.

13. Saraiva LLO, Melo FRLV. Avaliação e participação do fisioterapeuta na prescrição do mobiliário escolar utilizado por alunos com paralisia cerebral em escolas estaduais públicas da rede regular de ensino. Rev Bras Educ Espec. 2011;17(2):245-62. 